\title{
FY2003 LDRD Annual Report Article
}

\author{
J-H. Park, B. Baer, and C-S. Yoo
}

November 5, 2003

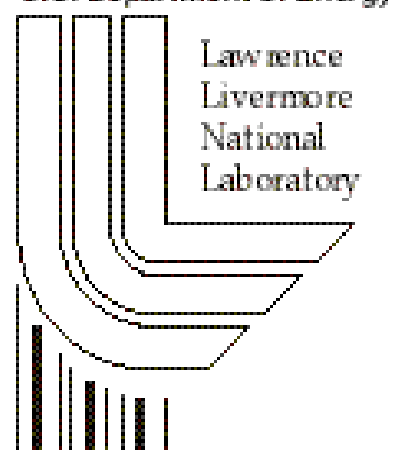


This document was prepared as an account of work sponsored by an agency of the United States Government. Neither the United States Government nor the University of California nor any of their employees, makes any warranty, express or implied, or assumes any legal liability or responsibility for the accuracy, completeness, or usefulness of any information, apparatus, product, or process disclosed, or represents that its use would not infringe privately owned rights. Reference herein to any specific commercial product, process, or service by trade name, trademark, manufacturer, or otherwise, does not necessarily constitute or imply its endorsement, recommendation, or favoring by the United States Government or the University of California. The views and opinions of authors expressed herein do not necessarily state or reflect those of the United States Government or the University of California, and shall not be used for advertising or product endorsement purposes. 


\section{FY2003 LDRD Annual Report Article}

\section{Annual Report Information}

Project Title:

Melting Studies of Simple Planetary Ices

Principal Investigator: Jae-Hyun Park

Responsible Directorate:

Primary Category of Work: Earth and Space Sciences

Secondary Category of Work: Physics

Type of Research: Basic

Tracking Code: 03-LW-020

Annual Report Authors: Jae-Hyun Park, Bruce Baer, Choong-shik Yoo

\section{Annual Report Text}

\section{Project Description}

This study proposes to deliver fundamental experimental data on the melt and phase diagrams of methane in an extended region of high pressures and temperatures. This study targets three major scientific areas: the constraint of planetary models for the outer-giant planets, discovery of exotic phases and insights for many-body intermolecular interactions of non-hard sphere and non-spherical molecules for which no reliable theory exists for these models as yet. In this study, we will adopt in situ at high pressures and temperatures by using both conventional and coherent anti-Stokes Raman spectroscopy applied to laser- or ohmic heated diamond-anvil cells. Structures of methane will be characterized by using intense, third-generation synchrotron x-ray diffraction.

\section{Expected Results}

By Raman spectroscopic studies, we demonstrated that the presence of N2 or heat treatment on high pressure methane shifts the phase boundaries among its various high pressure phases. Our synchrotron X-ray diffraction studies indicate that the presence of impurities can alte the equation of state of a pure substance significantly. Laser heating of pure methane shows that carbon and hydrogen is favored over methane or any other high order carbon chains.

\section{Mission Relevance}

Methane is the simplest organic molecule in which carbon is tetrahedrally bonded. It is well known that methane is a major component of some of the Jovian planets. Recently it was discovered that methane-water clathrates are abundant near the floor of deep oceans and are potentially a useful natural gas source. Given their importance to terrestrial investigations and astronomic models, the study of methaneÅfs high pressure phases as well as those of methane hydrates are in the progress. Moreover, methane is simply used as fuel. Therefore, its melt, and phase data are fundamental to understanding energy resources such as carbon management and environmental quality for the management as well as detonation chemistry. 


\title{
Accomplishments and Results
}

Methane samples loaded into diamond anvil cells were studied up to $55 \mathrm{GPa}$ in the temperature range of 25 to 450 oC by using Raman spectroscopy and synchrotron X-ray diffraction. By contrasting the results from a condensation loading method and one using a bellows, ther is strong evidence that the presence of an N2 impurity can shift the P-T phase boundaries. Sample heating is also observed to shift the phase boundaries metastably. These experiments resolve the conflicting results of previous literature reports. Pure methane at room temperature doesnÅft show any clear spectroscopic or cystallographic evidence of phase transition at least to $50 \mathrm{GPa}$. Laser heating experiments demonstrate that methane decomposes into carbon and hydrogen rather than producing higher order carbon chains.

Proposed Work

N/A

Does your current text contain possible patentable material? No

Project Coding $+\dagger+\dagger+\dagger+\dagger+\dagger+\dagger \dagger+\dagger$

Defense Programs: Yes

Environmental Management: No

Non-Prolif/National Security: No

\author{
Energy/Efficiency/Renew. Energy: No \\ Energy Research: No \\ Fossil Energy: No \\ Nuclear Energy: No \\ Department of Defense: No \\ Other: No
}

\section{People Information}

Foreign Nationals

Official First

ID:

Name:

Last

Name:

Country of

Origin:

park10 Jae-Hyun

Park

SOUTH KOREA

Country of

Residence:

SOUTH KOREA

none

Student Information

none

\section{Patents/Copyrights/Publications/Awards}

Patents

Date Discl: Date Appl: Date Grant: Patent Number: Patent Title: Inventors:

none

Copyrights

Date Discl:

\author{
Copyright Title:
}

none

Publications 


\begin{tabular}{|c|c|c|c|c|c|c|}
\hline Authors: & Title: & Journal: & Vol: & Page: & UCRL\#: & Pub Type: \\
\hline $\begin{array}{l}\text { Park J.-H., C. S. Yoo, } \\
\text { V. Iota, H. Cynn, M.F. } \\
\text { Nicol and T. LeBihan }\end{array}$ & $\begin{array}{l}\text { Crystal Structure of Bent } \\
\text { Carbon Dioxide; Precursor } \\
\text { to Polymerization }\end{array}$ & PRB & 68 & 014107 & UCRL-JC-151312 & Refereed publication \\
\hline $\begin{array}{l}\text { Iota V., J.-H. Park and } \\
\text { C.S. Yoo }\end{array}$ & $\begin{array}{l}\text { Phase Diagram of Nitrous } \\
\text { Oxide: Analogy with } \\
\text { Carbon Dioxide }\end{array}$ & PRB & $\begin{array}{l}\text { in } \\
\text { press }\end{array}$ & & UCRL-JC-153092 & Refereed publication \\
\hline Park, J.-H., et al. & $\begin{array}{l}\text { Crystal structures of bent } \\
\mathrm{CO} 2 \text { and } \mathrm{N} 2 \mathrm{O} \text { at high } \\
\text { pressures }\end{array}$ & $\begin{array}{l}\text { APS } 2003 \text { march } \\
\text { meeting, Austin, } \\
\text { TX, March3-7, } 2003\end{array}$ & $\mathrm{~N} / \mathrm{A}$ & & 150171-ABS & $\begin{array}{l}\text { Conference/Meeting } \\
\text { Abstract }\end{array}$ \\
\hline \multicolumn{7}{|l|}{ Awards } \\
\hline $\begin{array}{l}\text { Official ID: } \\
\text { park10 }\end{array}$ & $\begin{array}{l}\text { Last Name: } \\
\text { Park }\end{array}$ & $\begin{array}{l}\text { Award: } \\
\text { PAT directorate }\end{array}$ & Sponso & & & \\
\hline
\end{tabular}

